\title{
REVIEW OF THE MOST SIGNIFICANT CAVES IN MONTENEGRO
}

\section{PREGLED NAJPOMEMBNEJŠIH JAM ČRNE GORE}

\author{
Mirela DJUROVIĆ ${ }^{1} \&$ Predrag DJUROVIĆ ${ }^{2 *}$
}

\begin{abstract}
UDC 551.44(497.16)

Mirela Djurović \& Predrag Djurović: Review of the most significant caves in Montenegro

The most significant caves in Montenegro were distinguished in response to their physical-geographic, biological, archeological and morphometric characteristics (length and depth). Caves distribute in four distinctive regions: coastal karst, karst plateau (relict valley system), fluvial karst (recent hydrologic systems) and the high mountainous karst area. The most outstanding within the last, due to abundances of the major caves with depths from a few hundred meters to $1,162 \mathrm{~m}$, are four mountain regions: Mt. Durmitor, Mt. Lovćen-Orjen, Mt. Maganik and Mt. Bjelič.
\end{abstract}

Key words: caves, karst, Dinarides, Mt. Prokletije, Montenegro.

Izvleček

UDK 551.44(497.16)

Mirela Djurović in Predrag Djurović: Pregled najpomembnejših jam v Črni gori.

Najpomembnejše jame v Črni gori so bile proučevane glede na njihove fizikalno-geografske, biološke, arheološke in morfometrične lastnosti (dolžina in globina). Jame so porazdeljene $\mathrm{v}$ štirih različnih regijah, in sicer v obalnem krasu, na kraških planotah, fluvialnem krasu (recentni hidrološki sistemi) in na območjih visokogorskega krasa. Med zadnjimi z najpomembnejšimi jamami, globokimi od nekaj sto metrov do 1162 metrov, najbolj izstopajo štiri gorovja: Durmitor, Lovćen-Orjen, Maganik in Bjelič.

Ključne besede: jame, kras, Dinaridi, Prokletije, Črna gora.

${ }^{1}$ University of Belgrade, Faculty of Philosophy, Čika Ljubina 18-20, RS-11000 Belgrade, Serbia, e-mail: mirela.djurovic@gmail.com

${ }^{2}$ University of Belgrade, Faculty of Geography, Studentski trg 3/ III, RS-11000 Belgrade, Serbia, e-mail: geodjura@gmail.com

* Corresponding author 


\section{INTRODUCTION}

Speleological investigations in Montenegro have been done for more than a hundred years. During this period over a thousand caves were explored. At the beginning of twentieth century the Cave Duboki do (Sarkotič-Höle) worthies the deepest explored cave in a world (Lahner 1917, 1919). In the second half of $20^{\text {th }}$ century the exploration of caves was focused at different aspects: physical speleology, biospeleology, speleoarcheology, applied speleology (solutions of water-supply problems), geoheritage (Djurović \& Djurović 2010), as well as in attempt to identify the deepest and the longest caves. Speleological exploration within the last twenty years underwent dynamic evolution. This period characterizes the increasing interest and hunt for the deepest caves.
There are several available reviews on the subject of speleological researches and their achievements in Montenegro (Pretner 1961; Lješević 1980; Lješević \& Barović 1981; Maksimović 1997; Djurović 2017). A need for new review on the most significant speleological objects arose from the fact that passed many decades, since the very last review has been published, from that period a number of noteworthy caves were discovered. Therefore, the collection of data obtained throughout a range of studies carried out, their analyses, division and classification of the most significant caves were evaluated. The last two were employed by physical-geographic, biological, archeological and morphometric characteristics (length and depth) of caves.

\section{FACTORS AFFECTING SPELEOGENESIS}

The most important factors in speleogenesis in Montenegro (Fig. 1) are geological background, size and thickness of limestone, altitude and denivelation of karst relief, recent climate and relic and contemporary geomorphological processes.

Rocks of different composition and age (from Paleozoic to Quaternary) are exposed in Montenegro (Bešić 1975, 1980, 1983). The most abundant are diverse carbonate rocks of Mesozoic age that occur from the Adriatic coastal area till the highest mountain peaks $(>2,500$ $\mathrm{m}$ a.s.l.). The thickness of limestones ranges from a few hundreds to about $1,500 \mathrm{~m}$. In the central part of the state

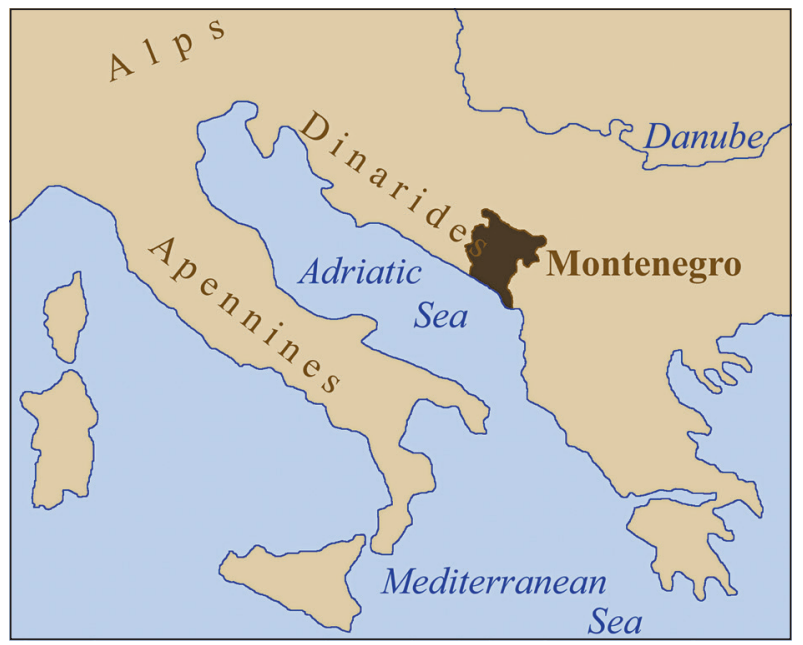

Fig. 1: Geographic position of Montenegro (Map by: Mirela Djurović). limestones are over 2,000 $\mathrm{m}$ thick. Carbonate rocks cover approximately $85 \%$ of the territory of Montenegro.

Mountainous relief is dominating in Montenegro. From its total spatial area of $13,812 \mathrm{~km}^{2}$ only $10 \%$ are plains (0-200 $\mathrm{m}$ a.s.l.) and approximately $56.7 \%$ of its territory exceeds $1,000 \mathrm{~m}$ a.s.l. (Mladenović 1984). Such distribution of vertical elevation had significant role in speleogenesis governing the direction of water circulation in karst.

Broad mountain plateaus are noteworthy in relief in Montenegro. They derived under fluvial- denudation processes from the Miocene through to Pliocene, i.e. during past geomorphological periods lack of tectonic events (Cvijić 1926; Milojević 1937). Most of plateaus occur at high mountain relief environments, between 700 and $1,450 \mathrm{~m}$ a.s.l. All are intensively karstified and some are cut by canyons whose depth commonly exceeds 1,000 m (Djurović \& Petrović 2007), supporting a vertical migration of water in karst.

Diversity of recent climate in karst regions is the consequence of their different elevation and distance from the sea. The average annual temperature ranges from $15.7^{\circ} \mathrm{C}$ (in coastal karst - Herceg Novi) (Burić et al. 2012) to $4.7^{\circ} \mathrm{C}$ (high mountainous karst - Žabljak) (Djurović 2012). The average air temperature in the highest karst terrains, about 2,050 m a.s.l., is approximately $1.6^{\circ} \mathrm{C}$. In regions of $2,500 \mathrm{~m}$ a.s.l. is only about $0.1{ }^{\circ} \mathrm{C}$ (Djurović 2011).

Montenegro receives the average annual precipitation of $1,798 \mathrm{~mm}$. During winter (October-March) precipitation reaches $1,223 \mathrm{~mm}$ (68\%), while in summer 
(April-September) is only $575 \mathrm{~mm}$ (32\%) (Radojičić 1996). The annual precipitation in karst regions depends on their distance from the sea, their altitude and orography. The highest precipitation, of approximately 4,604 $\mathrm{mm}$ annually, receives karst terrains on west of Montenegro, behind the Boka Kotorska Bay (Mt. Orijen). There has been recorded the absolute maximum of 7,067 mm in 1979 (Djurović \& Djurović 2016). Karst terrains on north of Montenegro (Mt. Durmitor - Žabljak) receive annually 1,453 mm (Djurović 2011), whereas in the highest karst terrains (>2,500 $\mathrm{m}$ a. s. 1.) this value approaches to 2,600 $\mathrm{mm}$ (Djurović 2012).

Relief of the karst terrains above $1,800 \mathrm{~m}$ a.s.l. is affected by cryo-nivation processes beside the recent karst ones (Milivojević \& Djurović 2010). Melting of snow, which retains during summer in a form of snowpack at high-mountainous karst terrain, produces meltwater that enable water to percolate for a pretty long period.

Glacial processes that took part at all high-mountainous karst terrains in Montenegro (Cvijić 1889, 1903, 1913; Milivojević 2007; Milivojević et al. 2008; Djurović 2009; Stepišnik \& Žebre 2011; Hughes et al. 2010, 2011;
Petrović 2014) had significant influence on speleogenesis of deep caves. Numerous morphological traces of glacial process (cirque, glacial valley, glacial sholders, nunataks, lateral and terminal moraines) reflect on the intensity of glaciation. Glacial process took part during three stages (Djurović 2009). The oldest phase considers MIS 12 (470$420 \mathrm{ka})$, the younger MIS $6(190-130 \mathrm{ka})$ and the last, cirque one MIS 5d - 2 (110 - $11.7 \mathrm{ka})$ (Hughes et al. 2011). Glaciers that were formed during the mentioned glacial phases accumulated huge amounts of water in the highest karst terrains. During interglacial phases, the melting of snow produced notable amounts of meltwater that is responsible for very intensive speleogenesis and deep karstification. Consequently very deep caves formed. Such deep karstification is confirmed by karst springs with considerable discharge. Such springs emerge at the bottom of deep canyons, karst poles or in the coastal area of Skadar lake and Adriatic Sea: Vukovo vrelo, Vidrovan, Gornjepoljski vir (Nikšićko polje), Ljutica (Canyon of the Tara river), Pivsko oko - $20 \mathrm{~m}^{3} / \mathrm{s}$ (Canyon of the Piva river) (Prohaska et al. 2004), spring Ljuta, Gurdić, Sopot, Spila (Boka Kotorska Bay), Karuč, Bolje sestre (Skadar Lake).

\section{METHODOLOGY}

Results of speleological researches in Montenegro could be found in different publications ranging from scientific and professional popular journals over different elaborates to advanced digital media services (sites of different speleological clubs, organizations, institutions and various informative services, etc.). Such a wide array of sources inevitably opens the question of whether the presented data are credible. Results presented in scientific journals were employed in their original forms as have been already scientifically approved. The data from other sources were subjected to critical analysis that included analyzing of graphical displays (quality and accuracy of detail ground plan, longitudinal and transverse section of caves) (Jeannin et al. 2007; Sirotek \& Weigel 2006), geographic location description, morphological and hydrological characteristics, as well as all other relevant data. The comparative analyses of obtained results with previous research results or those acquired by different researchers have been also applied (Yamaç 2018). Hence, all relevant parameters required for a cave to be included in a group of the most significant caves were critically analyzed.

The Map of the most significant caves in Montenegro has been created in a few stages. The first one included the delineating of karst areas using primarily the Basic geological map 1:100,000 SFR Yugoslavia (15 sheets) (Group of authors 1958-1968; Group of authors 1962-1966; Group of authors 1962-1967; Group of authors 1962-1967; Group of authors 1962-1969; Group of authors 1962-1969; Mirković et al. 1962-1968; Živaljević et al. 1964-1978; Mirković et al. 1965-1972; Mirković et al. 1967-1974; Mojsilović et al. 1973-1981; Mirković \& Vujisić 1980-1986). As geological formations on these maps were not distinguished regarding petrology but rather by principles of stratigraphy, the additional analyses including analysis of detail topographic maps 1:25,000 and aerial photographs and satellite images were obligatory for ambiguous parts (Benson \& Yuhr 2016). According to morphological, hydrological, climate and evolutionary data (Djurović 1998) the four distinctive karst regions, which are representative for karst specificities in Montenegro and caves within, were recognized during the second stage (Djurović 2017). The next, third stage, involved the classification of caves into five categories regarding their length, depth, hydrological, speleobiological and archeological characteristics. Afterwards, the geographic location of the each of the selected caves in Montenegro was designated on the map along with related graphical symbols. 


\section{REVIEW OF THE MOST SIGNIFICANT SPELEOLOGICAL OBJECTS}

According to present knowledge of speleological objects, the most significant caves in Montenegro are located in four regions, which were distinguished by morphological, hydrological, climate and evolutionary characteristics: coastal karst, karst plateau (relict river systems), fluvial karst (recent river systems) and high mountainous karst (Fig. 2).

Coastal karst is exposed along the coastal line of Adriatic Sea and Skadar Lake. Accelerated, glacialeustatic rise of sea-level (Matthews 1990; Peltier 1999; Lambeck \& Purcell 2005; Surić et al. 2005; Surić 2009; Slavec 2011), which correlates with the period after LGM (started before about $19 \mathrm{ka}$ and lasted till $7 \mathrm{ka}$ before), led to flooding of coastal caves (Lambeck \& Chappell 2001; Lambeck et al. 2002). Change in sea-level (recent rise of $\sim 1.8 \pm 0.3 \mathrm{~mm} / \mathrm{yr}$ is determined instrumentally) determined hydrological function of these caves that occur today either as permanent or intermittent karst springs (Church et al. 2004). During fluvial maximum their discharge is moderate (e.g., Ljuta $>180 \mathrm{~m}^{3}$ ) (Stevanović 2010). Springs are distributed at low altitudes and many of them are at least partly beneath the sea level, i.e. Skadar lake level. Majority of caves is in the Boka Kotorska Bay: Spila ( $N^{\circ} 8$ in Tab. 1), Sopot (No 9 in Tab. 1), Ljuta ( $\mathrm{N}^{\circ} 10$ in Tab. 1), Gurdić ( $\mathrm{N}^{\circ} 11$ in Tab. 1) (Renaud 1999; Guis 1999a, 1999b, 1999c; Milanović 2004; Eusebio et al. 2005a, 2005b; Mihajlovski 2006; Eusebio et al. 2007a, 2007b; Milanović 2007), along the coast of Skadar lake: Voločka Jama (No 25 in Tab. 1) (Otava \& Zajiček 1988, 1989, 1990; Szerszeń 2008; Graczyk 2011;) and Krevenica ( $\mathrm{N}^{\circ} 31$ in Tab.1). One of the most significant caves in mountainous karst is the cave Savino oko ( $\mathrm{N}^{\circ} 57$ in Tab 1.). Regardless of similar morphologic-hydrologic characteristics with the caves listed in the coastal karst region, it displays differences concerning its position (base of Prokletije), located at high altitude, type of speleogenesis, hydrogeological characteristics and so forth (Szerszeń 2008a, 2008b).

Karst plateau region in Montenegro (Cvijić 1926; Petrović 1997) displays similar characteristic to other karst plateau areas in Dinaric karst (Gams 2004; Bognar et al. 2012; Bočić et al. 2015). More than a few tenths of square kilometers of Montenegrin karst plateau is lack of surface water and the overall precipitation tends to disappear into limestones lying below. Karst plateaus are intensively karstified areas, and dotted by numerous dolines and karrens that form a peculiar topography, commonly inaccessible. Morphological records of relict valleys (Cotton 1968) significantly changed under karst processes meanwhile are also recognized in the relief of the karst plateau region beside a karst forms. According to the results of their reconstruction a few larger relict valleys systems have been distinguished. A number of caves of different morphological and hydrological characteristics, time and type of genesis, etc., within were explored.

Within the relict valley system Mt. Lovćen - Cetinjsko Polje - Skadar Lake are identified several long caves: Cetinjska Pećina ( No 22 in Tab. 1), Lipska Pećina ( No $^{\circ} 3$ in Tab. 1), Začirska Pećina (№ 26 in Tab. 1), Caves SpilaBabatuša ( $\mathrm{N}^{\circ} 27$ in Tab. 1), and Grbočica ( $\mathrm{N}^{\circ} 28$ in Tab. 1), (Petrović \& Božović 1980; Lješević \& Barović 1981; Mihevc 1983; Petrović 1997; Djurović et al. 2002; Lajovic 2010; Kovačević \& Kovačević 2014).

Caves in the other two relict valley systems are significantly deeper than the previous ones:

- the Mt. Lovćen - Njeguško Polje - Boka Kotorska Bay are: Nyúl Lika ( $\mathrm{N}^{\circ} 17$ in Tab. 1), Duboki Do ( $\mathrm{N}^{\circ} 18$ in Tab. 1), Njegoš Pećina ( $\mathrm{N}^{\circ} 19$ in Tab. 1), Bogoš Barlang Cave ( ${ }^{\circ} 20$ in Tab. 1), Cave Dögös ( $\mathrm{N}^{\circ} 21$ in Tab. 1), (Radulović 1974; Habič 1980; Lješević \& Barović 1981; Kiss \& Takácsné - Bolner 2006; Takácsné - Bolner 2006; Hegedűs et al. 2010; Hegedűs \& Takácsné - Bolner 2012, 2013),

- the Mt. Orjen - Grahovsko polje - Dragaljsko polje Boka Kotorska Bay: Gouffre du Brouillard (Maglena jama) (No 4 in Tab. 1), Cave Pištet PT4 (No 5 in Tab. 1), Cave Propast Pema ( No 7 in Tab. 1), (Dvořák \& Večerek 2001; Večerek \& Dvořák 2002; Groupe Spéléologique Minos 2003; Večerek et al. 2003; Dvořák 2004, 2009, 2010, 2011; Dvořák \& Dvořák 2008; Binding 2010; Duxbury 2010; Binding 2011; Duxbury \& Božović 2013).

Fluvial karst in its broadest sense represents karst region having both, the fluvial and the karst relief forms (Gams 2004; Bognar et al. 2012; Furlani et al. 2016; Phillips 2017; Donnaloia et al. 2019). It is found in the northern and northeastern parts of Montenegro. Canyons and gorges in karst plateau were incised by large allogenic rivers (Tara, Piva, Morača, Lim etc.) (Djurović \& Lješević 1994; Djurović \& Petrović 2007) that carried water in amounts large enough to incise limestone masses but to remain as surface flows due to impermeable basement. The main direction of flows and groundwater pathways in this part of Montenegro has been driven by the deeply incised canyons. Underground karst flows emerge at surface in a form of abundant karst springs either at the bottom of gorges and canyons: Djalovića gorge - Pećina nad Vražjim firovima ( $\mathrm{N}^{\circ} 53$ in Tab. 1) (Sirotek 2005, 2006, 2015) and, Juriško vrelo ( $\mathrm{N}^{\circ} 52$ in Tab. 1), Mrtvica canyon - Jama (№ 67 in Tab. 1) (Šimiček \& Kahle 2015) or on the margins of karst plateau: (Gornjepoljski Vir es- 
tavelle and intermittent spring - near the city of Nikšić), Ljutica (canyon Tara), Pivsko Oko (canyon Piva), Oraška jama and Oboštičko Oko (in the vicinity of Danilovgrad city). The pronounced discharge of springs reflects on complex but recent hydrologic systems, in which the direct speleological researches are extremely hard, even at the edge of possibility in regards to technical difficulties. In spite of a numerous karst springs, due to mentioned reasons, just a small number of caves have been explored in this region (Kličković 1997; Mirović 1997; Vučković \& Kličković 1997). A number of abris, which formed during different stages of evolution of river valleys, are also characteristic. In many of them were discovered Paleolithic settlements (Benac \& Brodar 1958; Brodar 1962; Basler 1975), as well as remains of Quaternary fauna (Bogićević \& Dimitrijević 2004; Argant \& Dimitrijević 2007).

High mountain karst is developed in a mountain highlands, which have been subjected to Pleistocene glacial processes allowing glacial karst to be formed (Stepišnik \& Žebre 2011; Djurović \& Djurović 2015). Currently is this area exposed to cryo-nivation processes along with the karst one (Lješević 2004; Milivojević \& Đurović 2010; Djurović 2011). Caves in high mountain karst were carved by melt water, not by erosion force of surface flows that sink into limestone bedrocks (Adamson et al. 2014; Žebre \& Stepišnik 2015). Meltwater, derived by widespread glaciers melting at the end of the oldest glacial phase (MIS 12) in high mountain regions in Montenegro, was the main agent in cave development primarily (Milivojević et al. 2008; Djurović 2009; Hughes et al. 2010, 2011). The second intensive developing phase took part during and at its end the Last glacial maximum. The influence of glaciers to speleogenesis terminated by melting of glaciers from the cirque glacial phase (MIS 5d-2), regardless the existence of current glacier Debeli namet at the Mt. Durmitor (Djurović 1999; Hughes 2007, 2008; Djurović 2012; Djurović \& Djurović 2016). Very important factors in speleogenesis in the current phase of the cave development are meltwater derived by melting of snow and snowpack at the surface, as well as accumulated snow and ice at the cave entrance. In a number of cave entrances were noted thick deposits of snow and ice (Gavrilović 1963) occasionally exceeding $100 \mathrm{~m}$ in thickness. Their melting enables the persistence of the erosion process in caves even in periods of lack of water supply from the surface. The deepest speleological objects occur in the highest levels of the high mountainous karst. Their abundance brought them the dominance within the most significant caves in Montenegro. Their entrances are in Pleistocene glacial forms (cirques and glacial valley) (e.g., Opasna Jama ( ${ }^{\circ} 32$ in Tab. 1) (Pavićević et al. 2015).
Daily and annual water regime is very specific due to snow, particularly due to snowpack. Maximal recharge in caves is related to the intensity of melting of snow and snowpack, instead to the amount of precipitation. Mountainous regions at Durmitor, Maganik and Bjelič, including Lovćen with its slopes, are distinguishing in number of deep caves. Examples at the Mt. Durmitor mountain are Bunda Jama ( $\mathrm{N}^{\circ} 34$ in Tab. 1), Jaskinia $\mathrm{X}$ 1108 ( $\mathrm{N}^{\circ} 36$ in Tab. 1), Jama na Vjetrenim Brdima ( ${ }^{\circ}$ 37 in Tab. 1), Jama Samo Lepo ( $\mathrm{N}^{\circ} 38$ in Tab. 1), Jamski Sitem u Obručinama ( ${ }^{\circ} 39$ in Tab. 1), Jama Fliš ( ${ }^{\circ}$ 40 in Tab. 1) and Jama u Malom Lomnom Dolu ( $\mathrm{N}^{\circ} 41$ in Tab. 1) (Lješević et al. 1980; Lješević \& Barović 1981; Mottram 1986; Garašić 1986a, 1986b, 1986c, 1986-1987; Courbon \& Chabert 1986; Jackson 1987; Milinčić et al. 1996; Ćalić - Ljubojević \& Mandić 2004; Vrviščar 2006; Podržaj 2009; Chojnacki 2010; Szczygieł 2010; Moody et al. 2013; Peters 2013). At the Mt. Maganik are beside the cave Iron deep ( $\mathrm{N}^{\circ} 47$ in Tab. 1 ), which exceeds 1,000 $\mathrm{m}$ in depth, also known: Jama u Pribatovom Dolu $\left(\mathrm{N}^{\circ}\right.$ 43 in Tab. 1), Jaskina Nyx (Jama u Treštenom vrhu) ( $\mathrm{N}^{\circ}$ 44 in Tab. 1), Aither ( $\mathrm{N}^{\circ} 45$ in Tab. 1), Jaskinia M13 ( ${ }^{\circ}$ 46 in Tab. 1), Zoran Jama ( $\mathrm{N}^{\circ} 68$ in Tab. 1) and Jaskinia M73 (No 48 in Tab. 1) (Vujić 1994, 1999; Maślanka 2008; Dvořák 2011a; Furtak 2012; Adamec et al. 2013; Dvořák \& Baldík 2013; Królewicz 2013-2017; Otava \& Baldík 2013; Dvořák 2014; Šimiček \& Kahle 2015). There are in the south part of the Mt. Prokletije (Bjelič) (Kardaś 1978): Jaskinia Do Savino Oko ( No 58 in Tab. 1), Jama frižider ( $\mathrm{N}^{\circ} 59$ in Tab. 1), Abisso degli Uomini Liberi ( $\mathrm{N}^{\circ}$ 60 in Tab. 1), Jaskinia Łezka - Jaskinia Kolektor ( $\mathrm{N}^{\circ} 61$ in Tab. 1) Cave Jaskinia Gornicza ( $\mathrm{N}^{\circ} 62$ in Tab. 1), Jaskinia Lodova ( $\mathrm{N}^{\circ} 63$ in Tab. 1), Jaskinia Gigant ( $\mathrm{N}^{\circ} 64$ in Tab. 1), Abisso dell'Ombra ( $\mathrm{N}^{\circ} 65$ in Tab. 1) and Jaskinia Niby Czarna ( ${ }^{\circ} 66$ in Tab. 1) (Kicińska \& Najdek 2007; Najdek 2007, 2008; Najdek \& Kasza 2008; Kasza et al. 2010a, 2010b; Kicińska et al. 2011; Santolin 2012; Kicińska \& Najdek 2009 - 2013; 2013; Najdek \& Kicińska 2013-2017; Vučetić \& Andjelić 2013). There are on Mt. Lovćen: Jama u Majstorima ( $\mathrm{N}^{\circ} 16$ in Tab. 1) (Skarep \& Trnavac 2004), System Jages barlang ( $\mathrm{N}^{\circ} 13$ in Tab. 1) Kétlyukú barlang ( $\mathrm{N}^{\circ} 14$ in Tab. 1) (Takácsné - Bolner et al. 2015) and Sistem Pala Skala ( ${ }^{\circ} 15$ in Tab. 1) (Mihalič et al. 2017; Tičar 2016; Tičar et al. 2017; Tičar \& Kozamernik 2018, 2018a). There are on the Mt. Orjen Jeskyně Kozí Díra ( $N^{\circ} 3$ in Tab. 1) (Dvořák \& Večerek 2001) and on Mt. Pivska planina Todorova Jama (№ 33 in Tab. 1) (Lješević 1976).

The early first description of cave animals in Montenegro (Neotrechus suturalis) dated back in 1864 to L.W. Schaufuss (Pretner 1961). Recognition of the most significant caves in regards to diversity of fauna (Pretner 1977; Nonveiller \& Pavićević 1999; Pavićević 1990; 
Pavićević et al. 1999; Karaman 2000) is difficult due to imprecise determination or referring of caves in which fossil fauna were found. In many caves presented in this paper, which were distinguished according some another criterions, were discovered habitats of diversified cave fauna: Lipska Pećina ( No 23 in Tab. 1), Grbočica $\left(\mathrm{N}^{\circ} 28\right.$ in Tab. 1), Jama na Vjetrenim Brdima $\left(\mathrm{N}^{\circ} 37\right.$ in Tab. 1). Particular importance deserve depicting of cave fauna in: Megara (№ 29 in Tab. 1) (Niphargus zorae, G. Karaman, 1967; Speonesiotes pretneri, Müller 1934; Speonesiotes montenegrinus Z. Karaman 1967); Speonesiotes laticollis, Müller 1934 (Müller 1934; Karaman 1967a, 1967b; Barović 1995), Lipska Pećina ( ${ }^{\circ} 23$ in Tab. 1) (Anthroherpon absoloni, Gueorguiev 1990; Folkia mrazeki, Nosek 1904; Bogidiella montenigrina, Karaman 1997; Neobisium umbratile, Beier 1938; Typhlogammarus mrazeki, Schäferna 1906) (Nosek 1904; Schäferna 1906; Beier 1938; Guéorguiev 1990; Karaman 1997), Grbočica $\left(\mathrm{N}^{\circ} 28\right.$ in Tab. 1) (Adriaphaenops staudacheri, Scheibel 1939; Elaphoidella montenegrina, Karanović 1997; Lithobius sketi, Matić \& Darabantu 1968; Niphargus brevicuspis sketi, Karaman 1966) (Scheibel 1939; Karaman 1966; Matić \& Darabantu 1968; Karanović 1997), Obodska Pećina ( $N^{\circ} 24$ in Tab. 1) (Plagigeyeria montenigrina Bole 1961; Saxurinator hadzii, Bole 1961; Spelaeodiscus obodensis, Bole 1964; Spelaeodiscus unidentatus, Bole 1961; Sphaeromides virei montenigrina, Sket 1957) (Sket 1957; Bole 1961, 1965), Jama na Vjetrenim Brdima ( $\mathrm{N}^{\circ} 37$ in Tab. 1) (Adriaphaenops zupcense tartariensis, Pavićević 2001; Tartariella durmitoriensis durmitoriensis, Nonveiller \& Pavićević 1999) Ledena Pećina ( $\mathrm{N}^{\circ} 35$ in Tab. 1) (Neotrechus hilfi grossi, Jeannel 1928; Leon- hardella antennaria antennaria, Apfelbeck 1907), (Nonveiller \& Pavićević 1999; Pavićević 2001). Of particular importance are also three caves where five troglobiotic beetle species were identified: Vilina Pećina ( $\mathrm{N}^{\circ} 6$ in Tab. 1) - Crkvice, Boljanovića Jama ( No 12 in Tab. 1) - Kotor and Pećina u Kučericama ( $\mathrm{N}^{\circ} 2$ in Tab. 1) - Mt. Orjen (Groupe Spéléologique Minos 2003; Zagmajster 2007), Pećina nad Vražjim firovima ( $\mathrm{N}^{\circ} 53$ in Tab. 1) (Remyella propiformis, Winkler 1933) (Moravec 2017).

Archeological and paleontological caves represent morphologically simple and short objects. Many of them are attributed to long-lasting accumulation of sediments that contributed to paleontological and archeological findings to remain preserved. They occur all over karst regions excluding high mountain area. The Lower Paleolithic findings were discovered in the cave Trlica $\left(\mathrm{N}^{\circ}\right.$ 49 in Tab. 1) (Dimitrijević 1990; Codrea \& Dimitrijević 1997; Crégut-Bonnoure \& Dimitrijević 2006; Argant \& Dimitrijević 2007; Derevjanko et al. 2012; Made \& Dimitrijević 2015; Vislobokova \& Agadjanian 2015). Traces of the Middle Paleolithic habitats were identified in Mališina Stijena ( $\mathrm{N}^{\circ} 51$ in Tab. 1), Bioče ( $\mathrm{N}^{\circ} 30$ in Tab. 1) and Crvena Stijena ( ${ }^{\circ} 1$ in Tab. 1) (Brodar 1962; Vogel \& Waterbolk 1972; Basler 1975; Brunnacker 1975; Malez 1975; Radovanović 1986; Bogićević \& Dimitrijević 2004; Đuričić 2006; Morley 2007). Remains of the Upper Paleolithic habitats are preserved in Crvena Stijena ( $\mathrm{N}^{\circ} 1$ in Tab. 1), Mališina Stijena ( $\mathrm{N}^{\circ} 51$ in Tab. 1), Medena Stijena ( $\mathrm{N}^{\circ} 50$ in Tab. 1) and Trebački Krš ( $\mathrm{N}^{\circ} 55$ in Tab. 1) (Benac \& Brodar 1958; Rakovec 1958; Malez 1975; Radovanović 1986; Nikolić 1992; Đuričić 1996; Dimitrijević 1999; Mihailović 2014).

Tab. 1: The most significant caves in Montenegro.

\begin{tabular}{|r|l|l|r|r|r|}
\hline No Name of cave & \multicolumn{1}{|c|}{ Location } & Entrance & Deep & Long \\
\hline 1 & Crvena stijena & Bilećko jezero & $725^{*}$ & 20 & - \\
\hline 2 & Pećina u Kučericama & Mt. Orjen & $*$ & \\
\hline 3 & Jeskyně Kozí díra & Mt. Orjen & 1011 & 662 & 1714 \\
\hline 4 & Gouffre du Brouillard (Maglena jama) & Mt. Orjen & 1120 & $>282$ & - \\
\hline 5 & Pištet (PT4) & Mt. Orjen - Kotor & 725 & 455 & - \\
\hline 6 & Vilina pećina & Mt. Orjen - Crkvice & $*$ & \\
\hline 7 & Propast Pema & Mt. Orjen & 680 & 318 & $>1500$ \\
\hline 8 & Spila & Risan & 20 & 72 & 410 \\
\hline 9 & Sopot & Risan & 29 & 70 & 400 \\
\hline 10 & Ljuta & Kotor & 20 & 133 & 170 \\
\hline 11 & Gurdić & Kotor & 0 & 52 & 460 \\
\hline 12 & Boljanovića jama & Kotor & 1320 & 216 & 944 \\
\hline 13 & Jages barlang & Mt. Lovćen & 1360 & 715 & 3600 \\
\hline 14 & Kétlyukú barlang & Mt. Lovćen & 1328 & 667 & 984 \\
\hline 15 & Sistem Pala skala & Mt. Lovćen & 1195 & 388 & \\
\hline 16 & Jama u Majstorima & Mt. Lovćen & 1112 & 400 & 1700 \\
\hline 17 & Nyúl lika/Zečija rupa & Njeguško polje & & \\
\hline
\end{tabular}


REVIEW OF THE MOST SIGNIFICANT CAVES IN MONTENEGRO

\begin{tabular}{|c|c|c|c|c|c|}
\hline 18 & Duboki do & \begin{tabular}{|l|} 
Njeguško polje \\
\end{tabular} & 997 & 505 & $>2247$ \\
\hline 19 & Pećina Njegoš & Njeguško polje & 874 & 308 & 5300 \\
\hline 20 & Bogoš & Njeguško polje & 1074 & 279 & $>1617$ \\
\hline 21 & Dögös barlang (Žestoka pećina) & Njeguško polje & 853 & 101 & 1100 \\
\hline 22 & Cetinjska pećina & Cetinje & 668 & 57 & 1067 \\
\hline 23 & Lipska pećina & Cetinje & 480 & +155 & 1810 \\
\hline 24 & Obodska pećina & Rijeka Crnojevića-Cetinje & * & & \\
\hline 25 & Voločka pećina & Skadar Lake & 6 & 47 & 250 \\
\hline 26 & Začirska pećina & Cetinje & 445 & 201 & 1173 \\
\hline 27 & Spila-Babatuša & Virpazar - Trnovo & $345 / 350$ & 55 & $290+$ \\
\hline 28 & Grbočica & Virpazar - Trnovo & 390 & 87 & 798 \\
\hline 29 & Megara & Podgorica & 283 & - & 260 \\
\hline 30 & Bioče & Canyon Morača & $*$ & & \\
\hline 31 & Krevenica & Tuzi & 37 & 50 & $>200$ \\
\hline 32 & Opasna jama & Mt. Žijovo & 1355 & $>500$ & $>2000$ \\
\hline 33 & Todorova jama & Mt. Pivska planina & 1660 & 297 & - \\
\hline 34 & Bunda jama & Mt. Durmitor & 2028 & 286 & 612 \\
\hline 35 & Ledena pećina & Mt. Durmitor & 2150 & 68 & 38 \\
\hline 36 & Jaskinia X 1108 & Mt. Durmitor & 2193 & 272 & 1799 \\
\hline 37 & Jama na Vjerenim brdima & Mt. Durmitor & 2175 & 775 & 1951 \\
\hline 38 & Jama Samo lepo & Mt. Durmitor & 2160 & 321 & - \\
\hline 39 & Jamski sitem u Obručinama & Mt. Durmitor & 2135 & 464 & $>2680$ \\
\hline 40 & Jama Fliš & Mt. Durmitor & 2080 & 582 & 1672 \\
\hline 41 & Jama u Malom lomnom dolu & Mt. Durmitor & 2098 & 605 & $>1870$ \\
\hline 42 & Jama u Crkvenom dolu & Mt. Maganik & - & 463 & - \\
\hline 43 & Dvogrla jama u Pribatovom dolu & Mt. Maganik & 1720 & 395 & - \\
\hline 44 & Jaskinia Nyx (Jama u Treštenom vrhu) & Mt. Maganik & 1950 & 622 & $>1000$ \\
\hline 45 & Jeskyně Aither & Mt. Maganik & 1920 & 380 & - \\
\hline 46 & M13 & Mt. Maganik & - & 333 & 765 \\
\hline 47 & Iron deep (Železna jama) & Mt. Maganik & 1767 & 1162 & 3360 \\
\hline 48 & Jaskinia M73 & Mt. Maganik & - & 473 & 646 \\
\hline 49 & Trlica & Pljevlja & * & & \\
\hline 50 & Medena stijena & Canyon Ćehotina & $*$ & & \\
\hline 51 & Mališina stijena & Canyon Ćehotina & $*$ & & \\
\hline 52 & Juriško vrelo & River Bistrica - Bijelo Polje & 747 & 35 & $>1000$ \\
\hline 53 & Pećina nad Vražjim firovima & River Bistrica - Bijelo Polje & 835 & - & 17500 \\
\hline 54 & Župan pećina & Lubnica selo, Berane & 1205 & 22 & 1160 \\
\hline 55 & Trebački krš & Berane & * & & \\
\hline 56 & Čardak & Mt. Greben - Gusinje & 1969 & 175 & 1054 \\
\hline 57 & Savino oko & Ropojana-Gusinje & 1000 & 90 & \\
\hline 58 & Jaskinia Do Savino Oko & Mt. Bjelič & 1998 & 256 & 588 \\
\hline 59 & Jama frižider & Mt. Bjelič & 2020 & 225 & 462 \\
\hline 60 & Abisso degli Uomini Liberi & Mt. Bjelič & 1910 & 402 & 849 \\
\hline 61 & Jaskinia Łezka-Jaskinia Kolektor & Mt. Bjelič & - & 263 & 1011 \\
\hline 62 & Jaskinia Gornicza & Mt. Bjelič & 2019 & 585 & 2083 \\
\hline 63 & Jaskinia Lodova (Ledena jama) & Mt. Bjelič & 1945 & 451 & 1956 \\
\hline 64 & Jaskinia Gigant & Mt. Bjelič & 2116 & 296 & 1635 \\
\hline 65 & Abisso dell'Ombra & Mt. Bjelič & 1969 & 250 & - \\
\hline 66 & Jaskinia Niby Czarna-Babina sisa & Mt. Bjelič & 1885 & 236 & 1611 \\
\hline 67 & Jama & Mt. Maganik (River Mrtvica) & 350 & 56 & 1244 \\
\hline 68 & Zoran Jama & Mt. Maganik & 1780 & $>630$ & - \\
\hline
\end{tabular}

*Arheological, paleontological or biospeleologically sites 


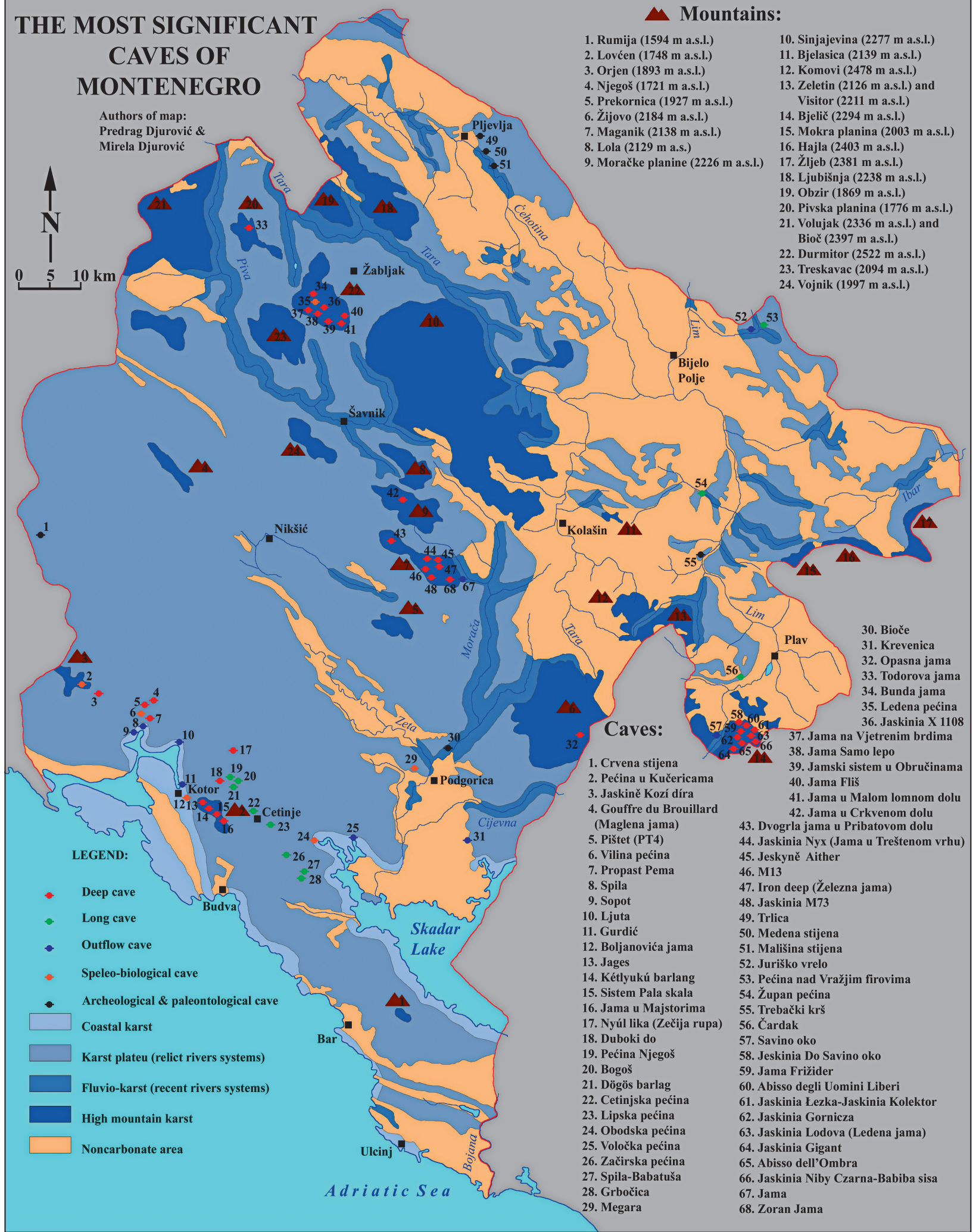

Fig. 2: Map of the most significant caves in Montenegro. 


\section{CONCLUSION}

The most significant caves in Montenegro expose from the coastal Adriatic Sea and the Skadar lake to the highest mountain peaks (regions exceeding 2,000 m a.s.l.). Caves formed in carbonate masses occasionally over 2,000 $\mathrm{m}$ thick. Their development is ascribed to a range of paleoclimate (glacial/interglacial) and recent climate conditions (mean annual temperature from 0 to 15 ${ }^{\circ} \mathrm{C}$ and mean annual precipitation of 1,500 to over 4,000 $\mathrm{mm})$. Their genesis is attributed to various forces: water melted from glacier, snowpatch and snow, erosion by rivers, glacial-eustatic rise of global sea level, etc. Many caves preserved traces of Paleolithic inhabitants and also represent habitats of diverse cave fauna. Four regions in the high mountainous karst are particularly outstanding in abundances of the most significant caves in Montenegro: Mt. Durmitor, Mt. Lovćen-Orjen, Mt. Maganik and Mt. Bjelič. Numerous caves vary in depth from a few hundred meters to $1,162 \mathrm{~m}$.

\section{REFERENCES}

Adamec, V., Baldik, V. \& Z. Dvořák, 2013: „Czech“ cave over one kilometre deep (Maganik Range, Montenegro).- In: Czech Speleological Society Speleoforum vol.23, 2013, Prague, 45-50.

Adamson, K.R., Woodward, J.C. \& P.D. Hughes, 2014: Glaciers and rivers: Pleistocene uncoupling in a Mediterranean mountain karst.- Quaternary Science Reviews, 94, 28-43. https://doi.org/10.1016/j. quascirev.2014.04.016

Apfelbeck, V., 1907: Leonhardella antennaria n. sp. - Societas entomologica, 22, 89.

Argant, J. \& V. Dimitrijević, 2007: Pollen analyses of Pleistocene hyaena coprolites from Montenegro and Serbia. - Geološki anali Balkanskoga poluostrva, 68, 73-80. https://doi.org/10.2298/GABP0701073A

Barović, G., 1995: Pećina Megara (Megara Cave).- In: Akademski speleološko alpinistički klub (Student Speleological and Alpinistic Club) Proceedings of the 2nd Symposium on Karst Protection, 1993, Belgrade, 209-214, Belgrade.

Basler, Đ., 1975: Stariji litički periodi u Crvenoj stijeni.In: Basler Đ. (ed.) Crvena stijena, Zbornik radova. Zajednica kulturnih ustanova, pp. 11-120, Nikšić.

Beier, M., 1938: Vorläufige Mitteilung über neue Höhlenpseudoscorpione der Balkanhalbinsel. Studien Gebiet. allgem. Karstforsch.wiss. Höhlenk. Eiszeitforsch. Nachbargebiet., Biol. Ser. 3, 1-8.

Benac, A. \& M. Brodar, 1958: Crvena Stijena - 1956.Glasnik Zemaljskog muzeja, (Ser. A) N.S., 13, 21-65.

Benson, R.C. \& L.B. Yuhr, 2016: Site Characterization in karst and pseudokarst terraines - Practical Strategies and Technology for Practicing Engineers, hydrologists and geologist.- Springer, pp. 421, Dordrecht. https:// doi.org/10.1007/978-94-017-9924-9

Bešić, Z., 1975: Geologija Crne Gore.- Društvo za nauku i umjetnost Crne Gore, knj. I, sv. 1, pp. 415, Titograd.
Bešić, Z., 1980: Geologija Crne Gore.- Društvo za nauku i umjetnost Crne Gore, knj. II, sv. 2, pp. 415, Titograd.

Bešić, Z., 1983: Geologija Crne Gore.- Društvo za nauku i umjetnost Crne Gore, knj. III, sv. 1, pp. 415, Titograd.

Binding, C.J., 2010: Expedition to the Kameno-More Region, Montenegro, 2009: The Exploration of Cave Pištet 4.- Proceedings of the University of Bristol Spelaeological Society, 25, 1, 35-46.

Binding, C.J., 2011: 2010 expedition to the Kamenomore region, Montenegro: further exploration in cave Pištet 4.- Proceeding of the University of Bristol Speleological Society, 25, 2, 125-131.

Bočić, N., Pahernik, M. \& A. Mihevc, 2015: Geomorphological significance of the palaeodrainage network on a karst plateau: The Una-Korana plateau, Dinaric karst, Croatia.- Geomorphology, 247, 55-65. https://doi.org/10.1016/j.geomorph.2015.01.028

Bogićević, K. \& V. Dimitrijević, 2004: Quaternary fauna from Mališina stijena near Pljevlja (Montenegro).Zbornik radova Odbora za kras i speleologiju VIII, 119-133.

Bognar, A., Faivre, S., Buzjak, N., Pahernik, M. \& N. Bočić, 2012: Recent Landform Evolution in the Dinaric and Pannonian Regions of Croatia.- In: Lóczy, D. et al. (eds) Recent Landform Evolution The Carpatho-Balkan-Dinaric Region. Springer, pp. 313344, Heidelberg, London, New York.

Bole, J., 1961: Nove vrste podzemeljskih polžev iz Črne gore. (Neue Subterrane schenken aus Črna Gora Jugoslavija).- In: Roglić, J. (ed.) Drugi jugoslavenski speleološki kongres, 1958, Split i Dalmatinska Zagora. Speleološki savez Jugoslavije, 205-207, Zagreb.

Bole, J., 1964: Die Vertreter der Gattung Spelaeodiscus Brusina 1886 (Gastropoda, Pulmonata) in Jugo- 
slawien.- International Journal of Speleology, 1, 3, 349-356. http://dx.doi.org/10.5038/1827-806X.1.3.9

Brodar, M., 1962: Crvena Stijena 1958. i 1959.- Glasnik Zemaljskog muzeja, (Ser. A) N.S., 17, 15-20.

Brunnacker, K., 1975: Die Sedimente der Crvena Stijena.In: Basler Đ. (ed.) Crvena stijena. Zbornik radova, Zajednica kulturnih ustanova, pp. 171-203, Nikšić.

Burić, M., Micev, B. \& L. Mitrović, 2012: Atlas klime Crne Gore. 1:500,000.- Leksikografski centar Crnogorska akademija nauka in umjetnosti, 2, Podgorica.

Chojnacki, T., 2010: Durmitor 2009.- Jaskinie, 58, 1, 19-20.

Church, J.A., White, N.J., Coleman, R., Lambeck, K. \& J.X. Mitrovica, 2004: Estimates of the regional distribution of sea level rise over the 1950-2000 period.- Journal of Climate, 17, 13, 2609-2625. https:// doi.org/10.1175/1520-0442(2004)017<2609:EOTR $\mathrm{DO}>2.0 . \mathrm{CO} ; 2$

Codrea, V. \& V. Dimitrijević, 1997: Stephanorhinus cf. hundsheimensis (TOULA) (Rhinocerotidae, Mammalia) from Trlica near Pljevlja (Montenegro).Geološki anali Balkanskoga poluostrva, 61, 2, 161177.

Cotton, C.A., 1968: Relict landforms. In: Geomorphology. Encyclopedia of Earth Science. Springer, Berlin, Heidelberg. https://doi.org/10.1007/3-540-310606_308

Courbon, P. \& C. Chabert, 1986: Atlas des grandes cavités mondiales.- Union Internationale de Spéléologie, Fédération Françaies de Spéléologie, pp. 255, La Garde.

Crégut-Bonnoure, E. \& V. Dimitrijević, 2006: Megalovis balcanicus sp. nov. and Soergelia intermedia sp. nov. (Mammalia, Bovidae, Caprinae), new Ovibovini from the Early Pleistocene of Europe.- Revue de Paléobiologie, 25, 2, 723-773.

Cvijić, J., 1889: Glacijalne i morfološke studije o planinama Bosne, Hercegovine i Crne Gore.- Glas SKA LVII, 21.

Cvijić, J., 1903: Novi rezultati o glacijalnoj eposi Balkanskog poluostrva.- Glas SKA LXV, 25.

Cvijić, J., 1913: Ledeno doba u Prokletije i okolnim planinama.- Glasnik Srpske Kraljevske Akademije nauka, XCI, 188-267.

Cvijić, J., 1926: Geomorfologija I.- Beograd.

Ćalić Ljubojević, J. \& M. Mandić, 2004: Nova speleomorfološka istraživanja jame na Vjetrenim brdima (Durmitor, Crna Gora).- In: Akademski speleološko alpinistički klub (Student Speleological and Alpinistic Club) Proceedings of the 5th Symposium on Karst Protection, 2004, Guča, 209-214, Belgrade.

Derevjanko, A., Šunjkov, M.V., Agadžanjan, A.K., Bulatović, L., Vislobokova, I.A., Uljanov, V.A., Ano- jkin, A.A. \& I. Medenica, 2012: Proučavanje pleistocenskih slojeva u pećini Trlica na sjeveru Crne Gore.- Davnine, I, 45-58.

Dimitrijević, V., 1990: Prvi rezultati istraživanja sisarske faune iz Trlice kod Pljevalja.- In: Denkovski, G. (ed.) Zbornik radova, XII Kongres na geolozi na Jugoslavija, I (Stratigrafija, sedimentologija, paleontologija), 1990, Ohrid. Geološko društvo na Makedonija, 328-336, Skopje.

Dimitrijević, V., 1999: Vertebrate fauna from the EpiGravettian site in Trebački Krš near Berane (Northeastern Montenegro).- In: Bailey, G.N. et al. (eds.) The Palaeolithic Archaeology of Greece and Adjacent Areas. British School at Athens, pp. 357-360, London.

Djurović, P. \& M. Lješević, 1994: Speleološki objekti Đalovića klisure i njihov značaj za cirkulaciju vode u krasu Peštera.- In: Zbornik radova Odbora za kras i speleologiju V, SANU, Beograd, 109-131.

Djurović, P., (ed) 1998: Speleological Atlas of Serbia.Geographical institute "Jovan Cvijic" SASA, pp. 290, Belgrade.

Djurović, P., 1999: Natural and anthropogenic influences as threats to pits in the Debeli namet glacier (Durmitor National park, Montenegro).- In: Andreo, B. et al. (eds.) Contribucion del estudio cientifico de las cavidades karsticas al conocimiento geologico, $17^{\text {th }}$ $20^{\text {th }}$ June 1999. Patronato da la Cueva de Nerja, Instituto de Investigacion, 579-585, Malaga.

Djurović, P., Milivojević, M. \& A. Petrović, 2002: Lipska pećina u svetlu novih morfo-hidroloških istraživanja.- In: Filipović, B. (ed.) XIII Simpozijum o hidrogeologiji $i$ inženjerskoj geologiji, $30^{\text {th }}$ May $-5^{\text {th }}$ June 2002, Herceg Novi. Komitet za hidrogeologiju i inženjersku geologiju, 1, 81-88, Podgorica.

Djurović, P. \& A. Petrović, 2007: Large Canyons of Dinaric and Prokletije Mountains Region of Monenegro. - Geographica Panonica, 11, 14-18. https://doi. org/10.5937/GeoPan0711014D

Djurović, P., 2009: Reconstruction of the pleistocene glaciers of Mount Durmitor in Montenegro.- Acta geographica Slovenica, 49, 2, 263-289. https://doi. org/10.3986/AGS49202

Djurović, P. \& M. Djurović, 2010: Objekti geonasledja reprezenti geodiverziteta Crne Gore.- In: Ivanović, S. et al. (eds.) Zbornik referata sa medjunarodnog naučnog skupa „Geoekologija - XXI vijek, teorijski $i$ aplikativni $z a d a c i$ “ $21^{\text {st }}-24^{\text {th }}$ September 2010 , Žabljak - Nikšić. Filozofski fakultet, 508-517, Nikšić.

Djurović, P., 2011: Visokoplaninski kras Durmitora. Posebno izdanje, Geografski fakultet, pp. 206, Beograd. 
Djurović, P., 2012: The Debeli Namet glacier (Durmitor, Montenegro) - From the second half of the 20th century to the present.- Acta Geographica Slovenica, 52, 2, 277-293. https://doi.org/10.3986/AGS52201

Djurović, M. \& Djurović, P., 2015: The impact of glacial processes in the evolution of the poljes of Montenegro.- Acta Geobalcanica, 1, 1, 25 - 31. https://doi. org/10.18509/AGB.2015.03

Djurović, P. \& M. Djurović, 2016: Physical geographic characteristics and sustainable development of the mountain area in Montenegro.- In: Zhelezov G. (ed.) Sustainable Development in Mountain Regions Southeastern Europe. Springer, pp. 93 - 111, Cham. https://doi.org/10.1007/978-3-319-20110-8_8

Djurović, P., 2017: General Speleological map of Montenegro. Author's edation, Belgrade.

Donnaloia, M., Giachetta, E., Capolongo, D. \& L. Pennetta, 2019: Evolution of fluviokarst canyons in response to the Quaternary tectonic uplift of the Apulia Carbonate Platform (southern Italy): Insights from morphometric analysis of drainage basins.- Geomorphology, 336, 18-30. https://doi. org/10.1016/j.geomorph.2019.03.008

Dvořák P. \& Z. Dvořák, 2008: „Nema konca, nema kraja, “aneb $654 \mathrm{~m}$ pod povrchem Orjenu (Černá Hora) Monte Negro 2007 Expedition.- In: Speleoforum vol. 27. Czech Speleological Society, 80-82, Prague.

Dvořák, Z. \& O. Večerek, 2001: Montenegro 2000.- In: Speleoforum vol. 20. Czech Speleological Society, 5657, Prague.

Dvořák, Z., 2004: Monte Negro 2003.- In: Speleoforum vol. 23. Czech Speleological Society, 54, Prague.

Dvořák, Z., 2009: Černá nora 2008 (Černá Hora) - Orjen 2008 Expedition, Monte Negro.- In: Speleoforum vol. 28. Czech Speleological Society, 83-87, Prague.

Dvořák, Z., 2010: A return to Pema, Montenegro.- In: Speleoforum vol. 29. Czech Speleological Society, 80-82, Prague.

Dvořák, Z., 2011: Krivošije 2010.- In: Speleoforum vol. 30, Czech Speleological Society, 80-81, Prague.

Dvořák, Z., 2011a: The Nyx and Aither Abysses.- In: Speleoforum vol. 30. Czech Speleological Society, 82-86, Prague.

Dvořák, Z. \& V. Baldík, 2013: Czech discoveries in the Maganik MTS., Montenegro.- In. Filippi, M. \& P. Bosák,(eds), 2013.. Proceedings of the 16th International congress of speleology. 21 -28 July 2013, Brno, Czech Speleological Society. Praha.2, 74-77.

Dvořák, Z., 2014: Iroan deep continued.- In: Speleoforum vol. 33. Czech Speleological Society, 72-77, Prague.

Duxbury, J., 2010 - Montenegro 2010. - Chelsea Speleological Society, 52, 168-171.

Duxbury, J. \& N. Božović, 2013: Pt4 cave (Ledenice, Crna
Gora).- In: Akademski speleološko alpinistički klub (Student Speleological and Alpinistic Club) Proceedings of the 7th Symposium on Karst Protection, 2011, Bela Palanka. Akademski speleološko alpinistički klub (Student Speleological and Alpinistic Club), 125-128, Belgrade.

Đuričić, Lj., 1996: The chipped stone industry from the rock-shelter of Trebački Krš. - In: Srejović D. (ed.) Prehistoric Settlements in Caves and Rock-shelters of Serbia and Montenegro. Faculty of Philosophy, Center for Archaeological Research, pp. 75-102, Belgrade.

Đuričić, Lj., 2006: A Contribution to Research on Bioče Mousterian.- Glasnik Srpskog arheološkog društva 22, 179-196.

Eusebio, A., Bordin, R., Jarre, R. \& G. Minciotti, 2005a: Crna Gora 2005 speleo-sub in Montenegro.- Speleologia, Rivista semestrale della Società Speleologica Italiana, 52, 60-67.

Eusebio, A., Bordin, R., Jarre, R. \& G. Minciotti, 2005b: Crna Gora 2005 - spedizione speleosubacquea italo - sloveno - montenegrina.- Speleologia Veneta, 13, 87-108.

Eusebio, A., Bordin R., Jarre, R. \& G. Minciotti, 2007a: Recenti esplorazioni speleosubacqueenel golfo di Kotor (Montenegro).- Thalassia Salentina, 30, 25-37.

Eusebio, A., Bordin, R., Jarre, R. \& G. Minciotti, 2007b: Montenegro 2005 - Spedicione speleosubacqea.Speleologia Veneta - Allegato scienfico, 5, 34-48.

Furlani, S., Finocchiaro, F., Boschian, G., Lenaz, D., Biolchi, S., Boccali, C. \& G. Monegato, 2016: Quaternary evolution of the fluviokarst Rosandra Valley (Trieste, NE Italy).- Alpine and Mediterranean Quaternary, 29, 2, 169-179.

Furtak, M., 2012: Nyx - bogini ciemności.- Jaskinie 3, 68, 11-12.

Gams, I., 2004: Kras v Sloveniji v prostoru in času.- Inštitut za raziskovanje krasa ZRC SAZU, pp. 515, Ljubljana.

Garašić, M., 1986a: International speleological expeditions in Yugoslavia in 1984 and 1985. - In: Trimmel, H. (ed.) Procedimento 9. Congresso International de Espeleologia, 1986, Barcelona, 1, 255-257.

Garašić, M., 1986b: Durmitor ' 86.- Bilten SSJ, II, 3, 17 18.

Garašić, M., 1986c: The International Speleological Expeditions of "Kamensko 84" and "Durmi tor 85", Yugoslavia.- British Caver, 98, 24-26.

Garašić, M., 1986-1987: Jama na Vjetrenim brdima u Durmitoru - najdublja jama u Jugoslaviji i na Balkanskom poluotoku.- Speleolog, 34, 35, 3.

Gavrilović, D., 1963: Snežnice na Lovćenu.- In: Zbornik radova $P M F$, sv. X. Geografski zavod, pp. 57-68, Belgrade. 
Graczyk, D., 2011: Kosowo i Czarnogóra - podwodne eksploracje 2011.- Jaskinie, 2, 63, 25-27.

Groupe Spéléologique Minos, 2003: Rapport de l'expédition Les Chemins de l'Orjen organisée par le Groupe Spéléologique Minos Expédition du 30 juillet au 20 août 2003 au Monténégro (Crna Gora). Groupe Spéléologique Minos.

Group of authors, 1958-1968: Osnovna geološka karta SFRJ 1: 100 000, list Gusinje, (Basic Geological Map SFRY 1:100 000, sheet Gusinje).- Zavod za geološka istraživanja SRCG, Titograd.

Group of authors, 1958-1968: Osnovna geološka karta SFRJ 1: 100 000, list Peć i Kukes (Basic Geological Map SFRY 1:100 000, sheet Peć i Kukes).- Zavod za geološka istraživanja SRCG, Titograd.

Group of authors, 1962-1966: Osnovna geološka karta SFRJ 1: 100 000, list Šavnik (Basic Geological Map SFRY 1:100 000, sheet Šavnik).- Zavod za geološka istraživanja SRCG, Titograd.

Group of authors, 1962-1967: Osnovna geološka karta SFRJ 1: 100 000, list Titograd (Basic Geological Map SFRY 1:100 000, sheet Titograd).- Zavod za geološka istraživanja SRCG, Titograd.

Group of authors, 1962-1967: Osnovna geološka karta SFRJ 1:100 000, list Bijelo Polje (Basic Geological Map SFRY 1:100 000, sheet Bijelo Polje).- Zavod za geološka i geofizička istraživanja, Beograd.

Group of authors, 1962-1967: Osnovna geološka karta SFRJ 1:100 000, list Nikšić (Basic Geological Map SFRY 1:100 000, sheet Nikšić).- Zavod za geološka i geofizička istraživanja, Beograd.

Group of authors, 1962-1969: Osnovna geološka karta SFRJ 1:100 000, list Budva (Basic Geological Map SFRY 1:100 000, sheet Budva).- Zavod za geološka i geofizička istraživanja, Beograd.

Group of authors, 1962-1969: Osnovna geološka karta SFRJ 1:100 000, list Kotor (Basic Geological Map SFRY 1:100 000, sheet Kotor).- Zavod za geološka i geofizička istraživanja, Beograd.

Guéorguiev, V.B., 1990: Recherches sur les Bathysciinae (Coleoptera: Catopidae) de Yougoslavie. I. Antroherponini. Acta entomologica musei nationalis Pragae, 42, 237-273.

Guis, M., 1999a: La Galerie exondée de Gurdic.- Bulletin de liason de la commission nationale Plongee souterraine, 4, 15-16.

Guis, M., 1999b: Krevenica.- Bulletin de liason de la commission nationale Plongee souterraine, 4, 14-15.

Guis, M., 1999c: Sopot.- Bulletin de liason de la commission nationale Plongee souterraine, 4, 16-17.

Habič, P., 1980: O kvartarnom razvoju Dubokega dola in Lipske pećine v Črni gori. - In: Vučković, M. \& V. Radulović (eds.) Sedmi jugoslovenski speleološki kongres, 1976, Herceg Novi. Savez speleologa Jugoslavije, 161-174, Titograd.

Hegedűs, A., Kiss, A. \& K. Takácsné - Bolner, 2010: Njeguši - Lovćen 2010.- In: Barlangkutatók Szakmai Találkozója, $13^{\text {th }}-14^{\text {th }}$ November 2010 , Esztergom, Magyar Karszt - és Barlangkutató Társulat Budapest, 5-8, Budapest.

Hegedűs, A. \& K. Takácsné - Bolner, 2012 - Lovćen Njeguši 2012. - In: Barlangi Denevérek Nemzetközi konferencia, $15^{\text {th }}-16^{\text {th }}$ November 2012, Pécs, Magyar Karszt - és Barlangkutató Társulat Budapes, 9-12, Budapest.

Hegedüs, A. \& K. Takácsné - Bolner, 2013: Njeguši - Lovćen 2013.- In: Barlangkutatók Szakmai Találkozója, $8^{\text {th }}-10^{\text {th }}$ November 2013, Szgedin, Magyar Karszt - és Barlangkutató Társulat Budapest, 14-16, Budapest.

Hughes, P.D., 2007: Recent behaviour of the Debeli namet glacier, Durmitor, Montenegro.- Earth Surface Processes and Landforms, 32, 10, 1593-1602. https://doi.org/10.1002/esp.1537

Hughes, P.D., 2008: Response of a Montenegro glacier to extreme summer heatwaves in 2003 and 2007.Geografiska Annaler Series A Physical Geography, 90, 4, 259-267. https://doi.org/10.1111/j.14680459.2008.00344.x

Hughes, P.D., Woodward, J.C., van Calsteren, P.C., Thomas, L.E. \& K.R. Adamson, 2010: Pleistocene ice caps on the coastal mountains of the Adriatic Sea.Quaternary Science Reviews, 29, 27-28. https://doi. org/10.1016/j.quascirev.2010.06.032

Hughes, P., Woodward, J., van Calsteren, P. \& L. Thomas, 2011: The glacial history of the Dinaric Alps, Montenegro.- Quaternary Science Reviews, 30, 3393-3412.

Jackson, C., 1987: Jama na Vjetenema Brona: Cave of the Windy Mountain, Durmitor.- Caves \& Caving, 37, 20.

Jeannel, R., 1928: Nouveaux Trechinae de la peninsule Balkanique. - Bulletin de la Société entomologique de France, 287-290.

Jeannin, P.Y., Groves C. \& P. Hauselmann, 2007: Speleological investigations.- In: Goldscheider, N. \& D. Drew (eds.) Methods in Karst Hydrogeology. International Assocciation of hydrogeologist. Taylor \& Francis, p. 264, London.

Karaman, G.S., 1966: III. Beitrag zur Kenntnis der Amphipoden aus Crna Gora.- Archives of Biological Sciences, Belgrade, 18, 2, 29-30.

Karaman, G.S., 1967a: I. Beitrag zur Kenntnis der Niphargus-arten (Amphipoda, Gammaridea) aus Crna Gora (Montenegro).- Fragmenta Balcanica, 6, 8, $143,73-80$.

Karaman, Z., 1967b: Une nouvelle espece du Karst, Speo- 
nesiotes montenegrinus n. Sp. (Col. Catopidae).Bulletin de la Societe entomologique de Mulhouse, 3, 63- 64 .

Karaman, G.S., 1997: Bogidiella montenigrina, n. sp. (Gammaridea, Fam. Bogidiellidae), one new species from Crna Gora (Montenegro) (Contribution to the Knowledge of the Amphipoda 217).- Glasnik Odjeljenja prirodnih nauka, Crnogorska akademija nauka i umjetnosti 11, 29-44.

Karaman, G.S., 2000: Amphipoda (Crustacea, Amphipoda) in the caves of Serbia and Crna Gora (Montenegro) (Contribution to the Knowledge of the Amphipoda).- In: Pantović, R.V. (ed) VIII Naučnostručni skup o prirodnim vrednostima i zaštiti životne sredine Ekološka istina, Zbornik saopštenja. Technical Faculty - Bor, University of Belgrade, 446-451, Sokobanja.

Karanović, T., 1997: Two new species of Harpacticoid copepods (Copepoda, Harpacticoida, Cathocamptidae) from Montenegro (Balkan Peninsula). - Bulletin of the Zoological Museum of the University of Amsterdam, 16, 1, 1-9.

Kardaś, R., 1978: Zjawiska krasowe w okolicach Gusinje (góry Prokletije, Jugosławia).- Kras i Speleologia, Uniwersytet Śląski, Katowice, 11, 2, 110-114.

Kasza, A., Kicińska, D. \& K. Najdek, 2010a: Jaskinie i zjawiska krasowe w górach Prokletije.- In: Szelerewicz, M. \& J. Urban (eds.) Materiały 44. Sympozjum Speleologicznego, $8^{\text {th }}-10^{\text {th }}$ October 2010, Wisła, 4647, Kraków.

Kasza, A., Kicińska, D., Najdek, K. \& Z. Tabaczyński, 2010b: Prokletije Belič 2009.- Jaskinie, 2, 59.

Kicińska, D. \& K. Najdek, 2007: Prokletije - góry przeklęte.- Jaskinie, 1, 46, 20-22.

Kicińska, D. \& K. Najdek, 2009 - 2013: Prokletije 2009 2013.- Polich caving, 2009-2013, 32.

Kicińska, D., Najdek, K. \& M. Filipiak, 2011: Prokletije 2010-2011.- Taternik, 2, 3, 40-45.

Kicińska, D. \& K. Najdek, 2013: Cave exploration of the Belić massif in the Prokletije mountains (Montenegro).- In: Filippi, M. \& P. Bosák (eds.) Proceedings of the $16^{\text {th }}$ International Congress of Speleology, 2013, Brno. Czech Speleological Society, 165-167, Praha.

Kiss, A. \& K. Takácsné - Bolner, 2006: Montenegro - Njegusi 2003.- Karszt és Barlang 2002-2003, 80-83.

Kličković, M., 1997: Preliminarni rezultati hidrohemijskih istraživanja u pećini nad Vražjim firovima (Preliminary results of hydrochemical research in the Cave over Devil's Whirlpools (Pecina nad Vrazjim Firovima).- Proceedings of the $3^{\text {th }}$ Symposium on Karst Protection, 1997, Belgrade. Akademski speleološko alpinistički klub (Student Speleological and Alpinistic Club), 223-232, Belgrade.
Kovačević, T. \& A. Kovačević, 2014: Južni Dinaridi Speleološki Eldorado.- Hrvatska vodoprivreda, 209, 81-85.

Królewicz, I., 2013-2017: Exploration in Maganik, Montenegro 2012-2016.- Polich caving, 2013-2017, 33 $-36$.

Lajovic, A., 2010: Jame u okolici Trnovega (Črna gora) Grbočica, Batuša i Špila.- Bilten. Jamarski klub Železničar, 27, 50-53.

Lahner, G., 1917: Der westmontenegrische Karst und sein hydrologischer Zusammenhang mit der Bucht von Cattaro.- Petermanns Geographische Mitteilungen, 63, 297-302.

Lahner, G., 1919: Im Karst der Schwarzen Berge.- Mitt. für Höhlenk, 8-12, Jg. 2-4, 1-36.

Lambeck, K. \& J. Chappell, 2001: Sea level change through the Last Glacial Cycle.- Science, 292, 5517, 679-686. https://doi.org/10.1126/science.1059549

Lambeck, K., Esat, T.M. \& E.K. Potter, 2002: Links between climate and sea level for the past three million years.- Nature, 419, 199-206.

Lambeck, K. \& A. Purcell, 2005: Sea-level change in Mediterranean Sea since the LGM: model predictions for tectonically stable areas.- Quaternary Science Reviews, 24, 18-19, 1969-1988. https://doi. org/10.1016/j.quascirev.2004.06.025

Lješević, M., 1976: Todorova jama.- Glasnik Republičkog zavoda zazaštitu prirode, 9, 173-180.

Lješević, M., 1980: Istraženost speleoloških objekata Crne Gore.- In: Vučković, M. \& V. Radulović (eds.) Zbornik radova, Sedmi jugoslovenski speleološki kongres, 1976, Herceg Novi. Savez speleologa Jugoslavije, 243-268, Titograd.

Lješević, M., 2004: Karst Pive.- Posebno izdanje, Crnogorska akademija nauka, pp. 296, Podgorica.

Lješević, M. \& V. Barović, 1981: Najveći speleološki objekti Crne Gore.- In: Gavrilović, D. (ed.) Zbornik radova, Osmi jugoslovenski speleološki kongres, 1980, Borsko jezero. Savez speleoloških organizacija SR Srbije, 201-205, Belgrade.

Lješević, M., Rósler, A. \& S. Belošev, 1980: Velike pećine i jame Durmitora.- In: Vučković, M. \& V. Radulović (eds.) Zbornik radova, Sedmi jugoslovenski speleološki kongres, 1976, Herceg Novi. Savez speleologa Jugoslavije, 271-282, Titograd.

Made, J. \& V. Dimitrijević, 2015: Eucladoceros montenegrensis n. sp. and other Cervidae from the Lower.Quaternary International, 389, 90-118. https://doi. org/10.1016/j.quaint.2015.02.058

Maksimović, D., 1997: Najduži i najdublji speleološki objekti u Jugoslaviji (Longest and deepest caves in Yugoslavia).- In: Proceedings of the $3^{\text {th }}$ Symposium on Karst Protection, 1997, Beograd. Akademski 
speleološko alpinistički klub (Student Speleological and Alpinistic Club), 191-200, Belgrade.

Malez, M., 1975: Kvartarna fauna Crvene Stijene.- In: Basler Đ. (ed.) Crvena stijena. Zbornik radova. Zajednica kulturnih ustanova, pp. 147-169, Nikšić.

Maślanka, A., 2008: Czarnogóra 2007/2008. - Jaskine, 4, $53,16-20$.

Matić, Z. \& C. Darabantu, 1968: Contributions à la connaissance des chilopodes de Yougoslavie.- Razprave, Slovenska Akademija Znanosti in Umetnosti, Razred za Prirodoslovne in Medicinske Vede, Ljubljana, 11, 5, 201-229.

Matthews, R.K., 1990: Quaternary sea-level change. Studies in Geophysics: Sea-Level Change.- National Academies Press, pp. 256, Washington.

Milanović, S., 2004: Speleoronjenje, značajan metod istraživanja i zaštite podzemnih vodad u karstu.Vodoprivreda, 36, 5-6, 427-439.

Milanović, S., 2007: Hydrogeological characteristics of some deep siphonal springs in Serbia and Montenegro karst.- Environmental Geology, 51, 5, 755-759.

Milinčić, M., Lješević, M. \& P. Djurović, 1996: Speleološka istraženost Nacionalnog parka „Durmitor". Priroda Nacionalnog parka Durmitor.- Posebno izdanje, 8, Geografski fakultat, pp. 68-86, Beograd.

Milivojević, M., 2007: Glacijalni reljef na Volujku sa Biočem i Maglićem.- Geografski institut „Jovan Cvijić" SANU, pp. 130, Beograd.

Milivojević, M., Menković, L. \& J. Ćalić, 2008: Pleistocene glacial relief of the central part of Mt. Prokletije (Albanian Alps).- Quaternary International, 190, 112122. https://doi.org/10.1016/j.quaint.2008.04.006

Milivojević, M. \& P. Djurović, 2010: Glacijalna i periglacijalna morfologija - indikator promene klime na planinama Crne Gore.- Zbornik referata sa medjunarodnog naučnog skupa "Geoekologija - XXI vijek, teorijski $i$ aplikativni zadaci", $21^{\text {st }}-24^{\text {th }}$ September 2010, Žabljak - Nikšić. Filozofski fakultet, 536-543, Nikšić.

Milojević, B., 1937: Visoke planine u našoj Kraljevini.Posebna izdanja, SKA, XIX, Beograd.

Mihailović, D., 2014: Paleolit na centralnom Balkanu kulturne promene i populaciona kretanja.- Srpsko arheološko društvo, 1-156.

Mihajlovski, M., 2006: Crna gora 2004 Potapljanje v kotorskih izvirih.- Bilten Jamarski klub Železničar, 25, 52-54.

Mihalič, K., Tičar, J., Bregar, L. \& M. Erker, 2017: Mednarodna jamarska odprava Zverinjačke rupe 2016.Dolenjski kras, 7, 160-168.

Mihevc, A., 1983: Lipska in Začirska pećina, dve veliki črnogorski jami.- Naše jame, 25, 37-40.

Mirković, M., Kalezić, M. \& M. Pajović, 1962-1968: Os- novna geološka karta SFRJ 1:100 000, list Bar (Basic Geological Map SFRY, sheet Bar 1:100 000).- Zavod za geološka istraživanja CRCG, Titograd (list Bar).

Mirković, M., Kalezić, M. Pajović, M. \& V. Đokić, 19621968: Osnovna geološka karta SFRJ 1:100 000, list Ulcinj (Basic Geological Map SFRY 1:100 000, sheet Ulcinj).- Zavod za geološka istraživanja CRCG, Titograd (list Bar).

Mirković, M., Pajović, M., Buzaljko, R., Kalezić, M. \& M. Živaljević, 1965-1972: Osnovna geološka karta SFRJ 1:100 000, list Pljevlja (Basic Geological Map SFRY 1:100 000, sheet Pljevlja).- Zavod za geološka istraživanja SRCG, Titograd.

Mirković, M., Pajović, M. \& M. Kalezić, 1967-1974: Osnovna geološka karta SFRJ 1:100 000 list Gacko (Basic Geological Map SFRY 1:100 000, sheet Gacko).Zavod za geološka istraživanja SR Crne Gore, Titograd.

Mirković, M. \& P. Vujisić, 1980-1986: Osnovna geološka karta 1: 100 000, list Žabljak (Basic Geological Map SFRY 1:100 000, sheet Žabljak).- Zavod za geološka istraživanja SR Crne Gore, Titograd.

Mirović, D., 1997: Pećina nad Vražjim firovima i drugi speleološki objekti u njenoj okolini i njihov odnos sa planiranom trasom auto-puta Beograd - crnogorsko primorje sa stanovišta zaštite životne sredine (The Cave Over the Vrazji Firovi and other caves and pits in its vicinity and their relation with a planned highway Belgrade - Montenegrin coast regarding environmental protection).- Proceedings of the $3^{\text {th }}$ Symposium on Karst Protection, 1997, Belgrade. Akademski speleološko alpinistički klub (Student Speleological and Alpinistic Club), 117126, Belgrade.

Mladjenović, T., 1984: Visinska struktura reljefa zemljišta u SFR Jugoslaviji.- Zbornik radova Vojnogeografskog instituta. Vojnogeografski institute, pp. 67-75, Belgrade.

Mojsilović, S., Baklajić, D., Živaljević, M. \& P. Vujisić, 1973-1981: Osnovna geološka karta 1:100 000, list Rožaje (Basic Geological Map SFRY 1:100 000, sheet Rožaje).- RO Geološki institute Beograd i Zavod za geološka istraživanja SR Crne Gore, Titograd.

Moody, C., Buxton, T., Sims, M. \& L. Bennett, 2013: YUCPC Durmitor 2013 Report.- The Ghar Parau Foundation, Fundling British Cave Exploration and Cave Science, 69.

Morley, M., 2007: Mediterranean Quaternary Rockshelter Sediment Records: A Multi-proxy Approach to Environmental Reconstruction.- PhD thesis, The University of Manchester, pp. 418.

Moravec, J., 2017: Recent records of Remyella propiformis A. Winkler, 1933 (Coleoptera: Leiodidae: Cho- 
levinae: Leptodirini) from the Đalovića Pećina Cave in Montenegro.- Studies and Reports Taxonomical Series, 13, 2, 425-427.

Mottram, L., 1986: 1986. International speleological expedition to Durmitor, Montenegro, Yugoslavia.The British Caver, 100, 20.

Müller, J.G., 1934: Diagnosi preliminari di nuovi coleotteri ipogei e cavernicoli. - Atti del museo civico di storia naturale di Trieste, 12, 176-181.

Najdek, K., 2007: Prokletije - Bjeshket e Namuna 2007.Taternik, 315-316, 3-4, 50.

Najdek, K., 2008: Prokletije - Bjeshket e Namuna 2008.Taternik, 319, 3, 46.

Najdek, K. \& D. Kicińska, 2013-2017: Cave exploration in the Prokletije Mountains (Montenegro).- Polich caving, 2013-2017, 29-32.

Najdek, K. \& A. Kasza, 2008: Prokletije - Bjeshket e Namuna 2008.- Jaskinie, 52 3, 21-24.

Nikolić, D., 1992: Mogućnost utvrdjivanja prirodnog okruženja praistorijskih zajednica na osnovu polenskih analiza.- In: Srejović D. (ed.) Arheologija $i$ prirodne nauke. Srpska akademija nauka i umetnosti, pp. 45-48, Beograd.

Nonveiller, G. \& D. Pavićević, 1999: Tartariella durmitorensis gen. et sp. n., troisième Leptodirini de la chaine dinarique à moeurs hadésiens (Coleoptera, Leiodidae, Leptodirini).- Bulletin de la Société entomologique de France, 104, 4, 315- 326.

Nosek, A., 1904: Pavoukovci členovci Černe Hory. Arachnoidea montenegrina.- Věstnik Kralovske Česke Společnosti Nauk, Třida MathematickoPřirodovědecka 1903, 46, 1-4.

Otava, J. \& V. Baldík, 2013: Geology and deep verticals: case study from Maganik MTS. - In: Filippi, M. \& P. Bosák (eds.) Proceedings of the $16^{\text {th }}$ International Congress of Speleology, 2013, Brno. Czech Speleological Society, 134-136, Praha.

Otava, J. \& P. Zajiček, 1988: Černá Hora 87.- In: Speleofórum vol.7. Czech Speleological Society, 43-48, Prague (In Czech, English summary).

Otava, J. \& P. Zajiček, 1989: Černá Hora 88.- In: Speleofórum vol. 8. Czech Speleological Society, 36, Prague (In Czech, English summary).

Otava, J. \& P. Zajiček, 1990: Černá Hora a Řecko 89.- In: Speleofórum vol. 9. Czech Speleological Society, 2930, Prague (In Czech, English summary).

Pavićević, D., 1990: Aphaenops (Adriaphaenops) zupcense sp. n. (Coleoptera, Carabidae, Trechinae).- In: Nonveiller, G. (ed.) The Fauna of Durmitor, 3. Special Editions, 23/14, The Montenegrin Academy of Sciences and Arts, pp. 355-362, Titograd.

Pavićević, D., Nonveiller, G. \& M. Popović, 1999: Diversity of troglobiontic coleopteran fauna of Durmitor
Mountain (Insecta, Coleoptera).- Protection of Nature, Belgrade, 51, 2, 103-110.

Pavićević, D., 2001: A new subspecies of aphaenops (Adriaphaenops) Zupcense Pavićević, 1990 from Durmitor, Montenegro (Coleoptera, Carabidae, Trechinae).- Acta entomologica Serbica, 6, 1-2, 3336.

Pavićević, M., Mišković, I., Janković, B. \& M. Gavrilović, 2015: Preliminarni rezultati speleoloških istraživanja jamskog sistema „Opasna jama“.- In: Ćalić, J. (ed.) Proceedings of the 8th Symposium on Karst Protection, $31^{\text {st }}$ October-!st November 2015, Pirot. Akademski speleološko-alpinistički klub (ASAK), 17, Pirot.

Peeters, A., 2011: Belgo-Serbian explorations on the massif of Durmitor (Montenegro) since 2008.- In: Ćalić, J. (ed.) Proceedings of the 7th Symposium on Karst Protection, 2011, Bela Palanka. Akademski speleološko alpinistički klub (Student Speleological and Alpinistic Club), 137-141.

Peltier, W.R., 1999: Global sea level rise and glacial isostatic adjustment.- Global and Planetary Change, 20, 2-3, 93-123.

Petrović, J. \& B. Božović, 1980: Razvoj sistema Cetinjskih pećina.- In: Vučković, M. \& V. Radulović (eds.) Zbornik radova, Sedmi jugoslovenski speleološki kongres, 1976, Herceg Novi. Savez speleologa Jugoslavije, 343-351, Titograd.

Petrović, J. 1997: Cetinjske pećine.- In: Petrović, D. \& J. B. Petrović (eds.) Morfologija i hidrografija kras. Zavod za udžbenike i nastavna sredstva, 365-432, Belgrade.

Petrović, A., 2014: A reconstruction of the pleistocene maximum in the Žijovo range (Prokletije moutains, Montenegro).- Acta geographica Slovenica, 54, 2, 255-269. http://dx.doi.org/10.3986/AGS54202

Phillips, J., 2017: Landform transitions in a fluviokarst landscape.- Zeitschrift für eomorphologie, 61, 2, 109-122. https://doi.org/10.1127/zfg/2017/0452

Podržaj, T., 2009: Mednarodna odprava v Črno goro.- Jamar, 2, 2, 10.

Pretner, E., 1961: Speleološka istraživanja u Crnoj Gori i spisak pećina i jama.- In: Roglić, J. (ed.), Drugi jugoslovenski speleološki kongres, (1-4. 4. 1958.) Split i Dalmatinska Zagora, Speleološki savez Jugoslavije, Zagreb, 219-235.

Pretner, E., 1977: Pregled podzemne faune koleoptera Crne Gore.- Glasnik odJeljenja prirodnih nauka, CANU, 2, 91-179.

Prohaska, S., Simić, Z., Orlić, A. \& V. Ristić, 2004: Osnovne hidrograafsko-hidrološke karakteristike sliva Drine i hidrometeorološki podaci.- Vodoprivreda, 36, 21-38. 
Radojičić, B., 1996: Geografija Crne Gore - prirodne osnove.- Univerzitet Crne Gore, pp. 228, Nikšić.

Radovanović, I., 1986: Nova istraživanja paleolita i mezolita u Crnoj Gori.- Glasnik Srpskog arheološkog društva, 3, 63-76.

Radulović, V., 1974: Ponori-jame i pećine kao pokazatelji napredovanja karstifikacije duž profila od Kotora do Crnojevića Rijeke.- Acta Carsologica, 111-125.

Rakovec, I., 1958: Pleistocenski sisavci u pripećku Crvena Stijena kod Petrovića u Crnoj Gori.- Glasnik Zemaljskog muzeja N.S. XIII, 65-75.

Renaud, M., 1999: Gurdic.- Bulletin de liason de la commission nationale Plongee souterraine, 4, 14-15.

Schäferna, K., 1906: O novem slepem blešivci, Typhlogammarus n. sbg.- Věstník Králivské české společnosti náuk, 26, 1-25.

Scheibel, O., 1939: Ein neuer Adriaphaenops aus Jugoslawien (Col.Carab).- Mitt. Münchner ent. Ges, XIII, 372- 374.

Sirotek, J., 2005: Expedition Medúza 2004.- In: Speleofórum vol. 24. Czech Speleological Society, 71-73, Prague (In Czech, English summary).

Sirotek, J., 2006: Medúza Expedition 2005.- In: Speleofórum vol. 25. Czech Speleological Society, 29-31, Prague (In Czech, English summary).

Sirotek, J., 2015: Medúza 2014.- In: Speleofórum vol. 34. Czech Speleological Society, 81-83, Prague. (In Czech, English summary)

Sirotek, J. \& J. Weigel, 2006: Speleological Mapping in the Northern Part of Moravina Karst.- In: Magel, H. (ed.) Proceedings Shaping the Change XXIII FIG Congress Münich, $8^{\text {th }}-13^{\text {th }}$ October 2006, Münich. International Federation of Surveyors, 1-9, Münich.

Skarep, I. \& D. Trnavac, 2004: Jama u Majstorima prilog speleološkim istražvanjima Lovćena.- In: Božić, N. (ed.) Zbornik radova. Društvo istraživača "Vladimir Mandić - Manda", 16, 97-107, Valjevo.

Sket, B., 1957: Einige neue Formen der Malacostraca (Crust.) aus Jugoslawien.- Bulletin Scientifique Section A: Sciences Naturelles, Techniques et Medicales, 3, 3, 70-71.

Slavec, P., 2011: Quaternary sea-level changes.- Geografski vestnik, 83, 1, 43-56.

Santolin, S., 2012: Spedizioni in Montenegro 2009/2010/2011.- Speleologia Emiliana, 3, V, 24-28.

Stepišnik, U. \& M. Žebre, 2011: Glaciokras Lovčena. Univerza v Ljubljani, Znanstvena založba Filozofske fakultete, Ljubljana, pp. 84.

Stevanović, Z., 2010: Case Study: Major springs of southeastern Europe and their utilization.- In: Krešić, N. \& Z. Stevanović (eds.) Groundwater Hydrology of Springs. Elsevier, 389-410, Oxford. https://doi. org/10.1016/B978-1-85617-502-9.00010-4
Surić, M., Juračić, M., Horvatinčić, N. \& I.K. Bronić., 2005: Late-Pleistocene-Holocene sealevel rise and the pattern of coastal karst inundataion: records from submerged speleothems alon the Eastern Adriatic Coast (Croatia).- Marine Geology, 214, 1-3, 163-175. https://doi.org/10.1016/j.margeo.2004.10.030

Surić, M., 2009: Reconstructing sea-level changes on the eastern Adriatic sea (Croatia) - An overview.-Geoadria, 14, 2, 181-199.

Szczygieł, J., 2010: Durmitor 2010.- Jaskinie, 61, 4, 27-28.

Szerszeń, A., 2008: Karst Springs of Skadarsko Jezero Expedition report. - Warsaw.

Szerszeń, A., 2008a: Wywierzyska Czarnogóry.- Jaskinie $1,50,23-24$.

Szerszeń, A., 2008b: Czarnogora - wywierzyska Jeziora Szkoderskiego - Grupa Nurkow Jaskiniowych.Taternik, 319, 3, 45.

Šimiček, O. \& V. Kahle, 2015: K vyverum Maganiku (destination - karst springs on the Maganik Plateau).Speleoforum, vol. 34, 62-65.

Takácsné - Bolner, K., 2006: Morfogenetikai megfigyelések a Njegusi-polje (Montenegro) Nagy Barlangjaiban karsztfejlődés.- KARSZTFEJLŐDÉS XI, 2006, Szombathely, 289-300 (in Hungarian).

Takácsné - Bolner, K., Hegedüs, A. \& D. Nagy Gergely, 2015: Rekord Montenegróban.- Barlangkutatók szakmai Találkozója, 2015, 5-7.

Tičar, J., 2016: Mednarodna jamarska odprava Zverinjačke rupe 2016, Lovćen, Črna gora, 30. 7.-14. 8. 2016.- Geografski vestnik 88-2, 169-172.

Tičar, J., Bregar, L., Erker, M. \& K. Mihalič, 2017: Mednarodna jamarska odprava Zverinjačke rupe 2016.Jamar, 9-1, 41-43.

Tičar, J. \& E. Kozamernik, 2018: Speleological expeditions in the central part of Mount Lovćen, Montenegro. - In: Mattes, J. et al. (eds.) Proceedings of the 12th EuroSpeleo Forum, 23 $3^{\text {rd }}-26^{\text {th }}$ August 2018, Ebensee. Verein für Höhlenkunde Ebensee, 51, Neukirchen.

Tičar, J. \& E. Kozamernik, 2018a: Mednarodna jamarska odprava Zverinjačke rupe 2017. - Jamar, 10-1, 43.

Yamaç, A., 2018: Double cave maps of Turkey.- In: Mattrs J. et al. (eds.) Proceedings of the 12th EuroSpeleo Forum, 23 ${ }^{\text {rd }}-26^{\text {th }}$ August 2018, Ebensee. Verein für Höhlenkunde Ebensee, 135, Neukirchen.

Večerek, O. \& Z. Dvořák, 2002: Montenegro 2001.- In: Speleoforum vol. 21. Czech Speleological Society, 53, Prague.

Večerek, O., Dvořák, Z. \& V. Kahle, 2003: Montenegro 2002.- In: Speleoforum vol. 22. Czech Speleological Society, 53, Prague.

Vogel, J.C. \& H.T. Waterbolk, 1972: Groningen Radiocarbon Dates X.- Radiocarbon, 14, 6-110. 
Vrviščar, B., 2006: Jama na Vjetrenim Brdima 2004.Bilten Jamarskega kluba Železničar, 52, 46-51.

Vislobokova, I.A. \& A.K. Agadjanian, 2015: New data on large mammals of the Pleistocene Trlica fauna, Montenegro, the Central Balkans.- Paleontological Journal, 49, 6, 651-667. https://doi.org/10.1134/ S0031030115060143

Vučetić, P. \& Andjelić, M., 2013: Preliminarni rezultati speleoloških istraživanja Jame frižider na Prokletijama.- In: Calić, J (ed.) Proceedings of the 7th Symposium on Karst Protection, 2011, Bela Palanka, Akademski speleološko alpinistički klub (Student Speleological and Alpinistic Club), 129-132.

Vučković, D. \& M. Kličković, 1997: Analiza prostornog položaja drenažnog sistema karstne izdani u funkciji tektonskog sklopa na primeru pećine nad Vražjim firovima (Analysis of regional orientation of karst aquifer draining system resulting from the tectonic framework - case study of Devil's Whirlpools Cave).- In: Proceedings of the $3^{\text {th }}$ Symposium on Karst Protection, 1997, Beograd. Akademski speleološko alpinistički klub (Student Speleological and Alpinistic Club), 213-222, Beograd.
Vujić, M., 1994: Podzemni oblici kraške erozije Mliječnog dola (planina Stožac).- In: Velimirović, M (ed.) Zbornik radova. Društvo istraživača „Vladimir Mandić Manda", 11, 89-104, Valjevo.

Vujić, M., 1999: Dvogrla jama u Pribatovom dolu.- In: Božić, N. (ed.), Zbornik radova, Društvo istraživača "Vladimir Mandić - Manda", Valjevo, 14, 77-84.

Zagmajster, M., 2007: Analysis of distribution patterns of model groups of troglobiotic fauna in the Dinaric region.- $\mathrm{PhD}$ thesis, Univerza v Ljubljani, Biotheniška fakulteta, pp. 128.

Žebre, M. \& U. Stepišnik, 2015: Glaciokarst landforms and processes of the southern Dinaric Alps.- Earth Surface Processes and Landforms, 40, 11, 14931505. https://doi.org/10.1002/esp.3731

Živaljević, M., Vujisić, P., Mirković, M., Djokić, V. \& M. Čepić (1964-1978): Osnovna geološka karta SFRJ 1:100 000, list Ivangrad (Basic Geological Map SFRY 1:100 000, sheet Ivangard).- Zavod za geološka istraživanja SRCG, Titograd. 
